\title{
BEHAVIOUR PECULIARITIES OF ADOLESCENTS WITH INTELLECTUAL DISABILITIES IN CONFLICT SITUATIONS
}

\section{Bystrova Yu. 0.}

\section{INTRODUCTION}

This study is highly relevant as there is a need to organise conditions for the socialization of children with special educational needs in special and inclusive education institutions. This particularly includes school psychological support for adolescents with intellectual disabilities, who find themselves in difficult-to-solve conflict situations on an everyday basis. For such children, the process of socialisation occurs with particular complications. A number of scholars, such as S. Konoplyasta, M. Pevzner, O. Proskurniak, L. Rudenko, D. Shulzhenko, V. Syniov, substantiate that intellectual disability negatively affects the state of emotional and volitional sphere; moreover, it facilitates social behaviour violations. Such wellknown scientists as O. Ahavelian, I. Dmytriieva, S. Myronova, M. Matvieieva, O. Romanenko, O. Sievierov, V. Syniov state that weak self-regulation or lack of it in relations with other people reduces the possibility of choosing the right way to overcome difficulties, control actions, and keep proper awareness of the situation. A particular aggravation of these problems occurs in adolescence, which can be easily explained by the instability of nervous system during puberty ${ }^{1}$. Bozhovich (1995) emphasized that the combination of two factors - disharmony and tension during the occurrence of sexual metamorphosis, as well as decompensation of various types of CNS insufficiency - leads to the fact that the pathological temper features and mental deviations, which are associated with decompensation of organic insufficiency of the CNS, come to the boil and, consequently, conflicts arise in the teenage

1 Бистрова Ю.О. Забезпечення наступності в процесі професійно-трудової соціалізації осіб з вадами інтелектуального розвитку : монографія. Луганськ : Вид-во ДЗ «ЛНУ імені Тараса Шевченка».2012. С. 156-217. 
phase of development more often than in other critical age phases of childhood $^{2}$.

In this regard, one of the important elements of the socialisation of adolescents with intellectual disabilities is to prevent their conflict behaviour and to facilitate conflict resolution both with their peers and in their relations with those around them.

Taking into account the negative impact of conflicts on the social adaptation of children and adolescents with intellectual disabilities, we would like to emphasize the relevance of the research problem for special psychology. Such issues as determining the causes and dynamics of conflict behaviour require particular attention in order to define the possibilities and methods of correctional influence aiming to prevent and resolve conflicts in the behaviour of students with intellectual disabilities.

\section{Analysis of Subjective Psychological Preconditions for the Emergence of Conflicts in the Behaviour of Adolescents with Intellectual Disabilities}

The study took place throughout 2017-2019 and included two stages. 120 adolescents studying in special educational institutions, and 120 adolescents from general education schools of Luhansk, Kiev, Cherkasy and Ternopil Oblasts participated in the experiment. 60 younger teens with intellectual disabilities from $5^{\text {th }}$ to $7^{\text {th }}$ grades (30 girls and 30 boys) and 60 senior teens from $8^{\text {th }}$ to $9^{\text {th }}$ grades (30 girls and 30 boys) participated in the study.

At the first stage, the research team identified the main issues faced by adolescents with intellectual disabilities in terms of interpersonal communication, acknowledged the specific situations causing conflicts and peculiarities of behaviour in these cases. After analysing relevant psychological literature, the team selected appropriate methods / techniques.

At the second stage, the team identified experimental groups and conducted a confirmatory experiment. Its main task was to study the causes and characteristics of conflict behaviour in adolescents with intellectual disabilities.

${ }^{2}$ Божович Л.И. Избранные психологические труды. Проблемы формирования личности. / под ред. Д.И. Фельдштейна. М. : Международная педагогическая академия, 1995. 349 с. 
The selection of methods and techniques was based on understanding of the essence of conflict and the dependence of the peculiarities of conflict behaviour on the factors of its occurrence. In order to cover the entire spectrum of issues, the researchers applied the following methods / techniques:

(1) studying subjective assessment, objective causes of conflicts and behaviour peculiarities of adolescents with intellectual disabilities in conflict situations;

(2) studying behaviour strategies, emotional responses in conflict, ways of overcoming and solving difficult life situations.

Adolescents with intellectual disabilities find it difficult to perceive many formulations of personality questionnaires. Considering this fact, the researchers selected the tests that were equally easily perceived by adolescents from general and special schools. When working with tests and questionnaires for adolescents with intellectual disabilities, the primary focus was on instructions: first, they explained the general terms, and then gradually provided other information. The surveyed teenagers performed the tasks individually and this process was accompanied by a conversation between a student and a psychologist. During the conversation with adolescents, the expert revealed their understanding of conflict and conflict behaviour, the ability to assess conflictual relationships with peers and teachers. It was vital to identify the types of adolescents' reaction to teachers' pedagogical influence in a particular conflict situation. In order to study the prevailing strategies of conflict behaviour and ways to overcome difficulties, we used the adapted version of K. Thomas model ${ }^{3}$ and the S.Rozentzweig pictureassociation method ${ }^{4}$. We studied the emotional state of adolescents in conflict interaction using the Phillips School Anxiety Questionnaire $(\mathrm{SAQ})^{5}$, Coping Strategies ${ }^{5}$ and Hand Test $^{5}$. The projective techniques commonly known as incomplete sentences or sentence completion

${ }^{3}$ Бистрова Ю.О., Синьов В.М. Діагностика індивідуально-психологічних рис особистості як початковий етап процесу професійно-трудової соціалізації учнів 3 особливими освітніми потребами. Nowoczesna edukacja: flozofa, innowacja, doświadczenie. Nr1. Łódź : Wydawnictwo Naukowe Wyższej Szkoły Informatyki i Umiejętności, 2015. P. 120-129.

Лукин С.Е. Суворов А.В. Тест рисуночной ассоциации Розенцвейга (руководство по использованию). СПб., 1993. 62 с.

5 Спеціальна психолого-педагогічна діагностика / за ред. Ю.О. Бистрова, В.Є. Коваленко. Харків: Майданс, 2018. 170 с. 
method and René Gilles film test (Le Test-Film) ${ }^{5}$ aimed at identifying images and subjective psychological preconditions for conflicts in the closest social environment (family and school), at studying personal orientations (goals, values), individual and typological features of emotional sphere (fears, expectations, anxieties) of teenagers with intellectual disabilities. The ascertaining experiment also included the observation of adolescents during the classes and in the communication period not regulated by the teacher. In the process of observing the adolescents, the researchers carried out a thorough record of teenagers' actions, statements, emotional manifestations, the nature of response to the direct action of another adolescent or teacher, and typical ways of responding to various conflict situations. In addition to the abovementioned, the method of ascertaining experiment included analysis of school and medical documentation (medical records and inspection cards).

Basing on general concepts, one of the tasks was to identify the subjective psychological preconditions for the emergence of conflicts in adolescents with intellectual disability, because psychologists, particularly G. Lozhkin and N. Poviakel, confirm that subjective factors, above all, can transform the potential conflict into a real one ${ }^{6}$. In the course of the study, the researchers discovered that most often in adolescents with intellectual disabilities relationships with peers, less often with adults become the cause of negative emotional states that lead to conflict behaviour. At the same time, as adolescents grow a little bit older, they experience increasing dissatisfaction with relations in the system of "teacher - student", moreover, this feeling is both subjective and objective. The very personality of the teacher becomes a subject that is undesirable for contacts and communication. Difficult situations of interaction with a teacher cause anxiety in younger adolescents (76.7\%) and convert into aggression and rejection in older teenagers (86.7\%). Many teens expect negative assessment from a teacher (20\% of younger ones, $36.7 \%$ of older ones). Comparing both adolescent groups, we should note that older teens feel less anxiety in a number of school-related issues, such as the fear of a knowledge test $(\mathrm{p}<0.001)$, but they are more likely to be afraid of not meeting the

6 Ложкин Г.В., Повякель Н.И. Практическая психология конфликта. К. : МАУП, 2002. С. 66-74. 
expectations of others $(\mathrm{p}<0.05)$. Unlike the general secondary school, in the special school anxiety grows towards senior grades due to the worsening of their relationships with peers (from $10 \%$ in younger teens, up to $20 \%$ in older ones). The responses of adolescents reflect asocial forms of behaviour (cruelty, substance abuse) as one of the possible negative aspects of adolescent communities. Many students with intellectual disabilities experience negative attitude of their peers $(20 \%$ of younger ones, $30 \%$ of older ones). Besides, they note the terrible habits of their mates: "My friends often beat me", "... like to drink vodka", "... carry knife","... sniff glue". There is an increase in the number of cases of negative evaluation of their relationships with peers in senior grades, due to the increase in conflicts among the older adolescents with intellectual disabilities. This is linked to the later personality formation of an adolescent studying in a special school in comparison with the adolescent of a general secondary school. Closer to senior grades an adolescent with intellectual disabilities begins to realise both his/her personal and social inferiority. This awareness prevents him/her from succeeding in various fields that attract the teenager, and thus increases anxiety in this regard $(\mathrm{p}<0.01)$.

In the course of the study, the researchers studied the factors of school life that influence the formation and predominance of a strategy of conflict behaviour in adolescents with intellectual disabilities. The factors that shape positive behaviour include adequate teachers' requirements for an adolescent, the satisfaction of the adolescent with his/her activities and relationships with others, increased motivation to study, the lack of conflict-related conditions during the classes and in extra hours. The negative factors that shape the destructive behaviours of adolescents with intellectual disabilities include peers and teachers ignoring the individuality of the adolescent, the lack of increased motivation to study, aggression from peers, the use of conflictogens and the negative assessment of teachers ${ }^{7}$.

The research showed that family education plays a great role in the formation of positive or destructive behaviour of adolescents with

7 Бистрова Ю.О. Забезпечення наступності в процесі професійно-трудової соціалізації осіб з вадами інтелектуального розвитку : монографія. Луганськ : Вид-во ДЗ «ЛНУ імені Тараса Шевченка». 2012. С. 156-217. 
intellectual disabilities in conflict situations ${ }^{8}$. The scientists determined that reasons causing conflicts in the family include the family neglect of a teen (by parents), the abuse of alcohol in the family, immoral behaviour of family members, anxiety and fear of family members, the fear of losing one of the parents. Often, younger teenagers with intellectual disabilities say that the family members shout at them (42\%), scold them (44\%), call them all names (17\%), undeservedly offend them (33\%), can beat them (15\%); $17 \%$ of older teens and $9 \%$ of the younger ones have heard from their father or mother that they do not love them. It is important to note the fact that in individual conversations, 20-25\% of adolescents say that their parents take it out on them. This means that every fourth teenager experiences pressure because of parental problems. Thus, family discomfort is reflected in adolescents by displaced aggression, often stressed by scientists while considering types of psychological protection ${ }^{9}$. Factors weakening and preventing conflicts are positive relationships with parents, the inclusion of a teenager with intellectual disabilities, help that $\mathrm{s} / \mathrm{he}$ gets in difficult situations, confidence in love, protection and support from the family. The study found that in the majority of cases the personal traits that were laid down by the family upbringing determine the behaviour strategy of the adolescent with intellectual disabilities in a conflict - family shapes and consolidates certain stereotypes of behaviour: dependent (adaptation), detached (avoidance) and aggressive (destructive rivalry).

\section{Strategies for Behaviour in the Conflict of Adolescents with Intellectual Disabilities}

The next task, solved in the research, was to study the influence of the level of mental development, age characteristics and gender differences of adolescents on the choice of strategies for behaviour in difficult situations that are difficult to solve. The scholars clarified it by the method of comparative analysis of various groups of adolescents (teenagers with intellectual disabilities and adolescents with normal development type).

8 Бистрова Ю.О. Забезпечення наступності в процесі професійно-трудової соціалізації осіб з вадами інтелектуального розвитку : монографія. Луганськ : Вид-во ДЗ «ЛНУ імені Тараса Шевченка». 2012. С. 156-217.

9 Ложкин Г.В., Повякель Н.И. Практическая психология конфликта. К. : МАУП, 2002. С. 66-74. 
While examining the study results based on the adapted version of American social psychologist K. Thomas model, we noted that there were no reliable quantitative differences in the ways of responding to a conflict situation as a result of comparison of groups of adolescents with different levels of mental development, except for cooperation strategy (see Fig. 1).

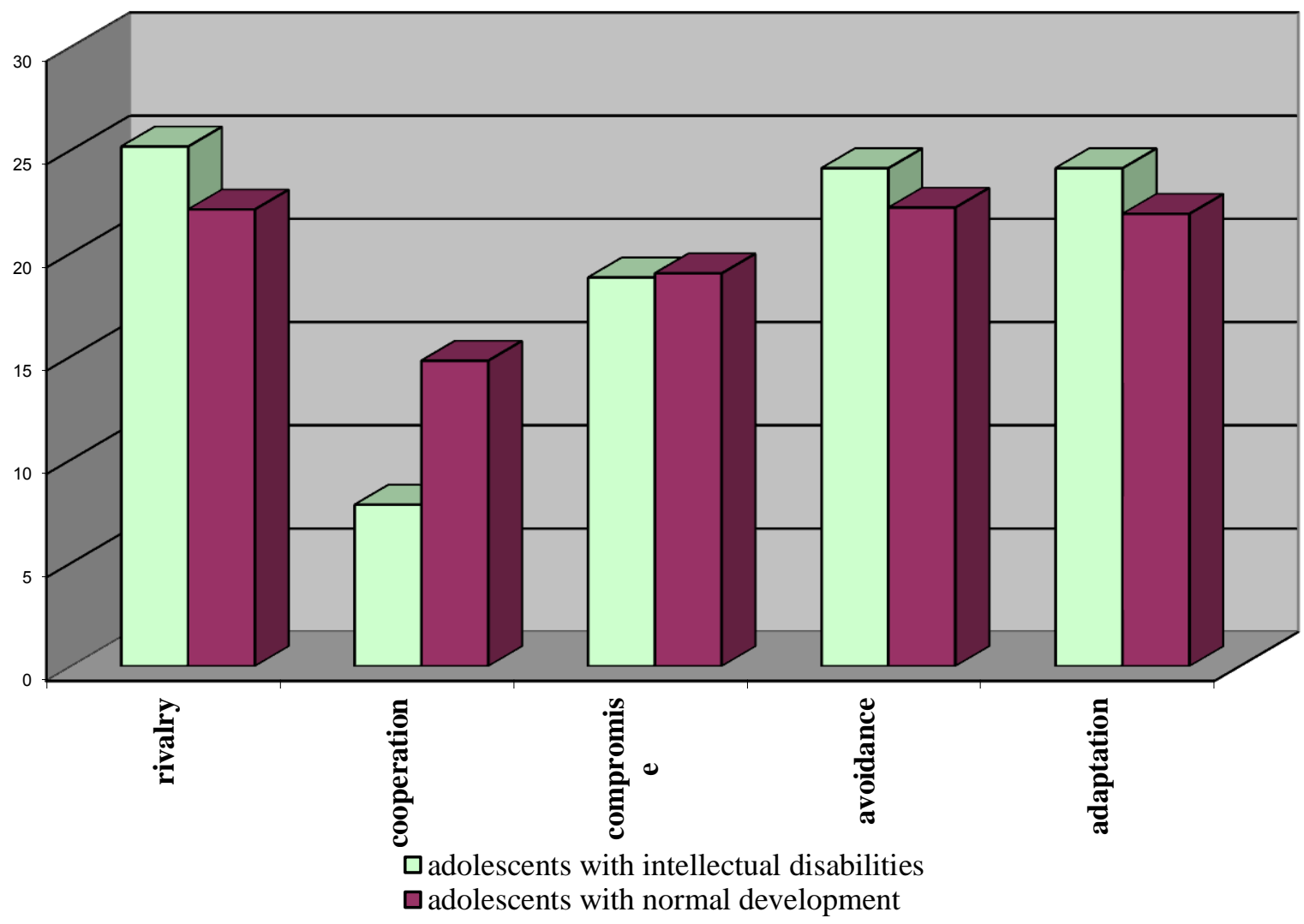

Fig. 1. The Most Preferred Strategies of Conflict Behaviour in Adolescents with Intellectual Disabilities and Normal Development

The choice of cooperation strategy of in a general education school is almost twice as high as in a special school. We should clarify that this comparison was taken as a percentage from the number of all choices in the group. In the future, for more explicit data, we will use the average quantitative indicators of the intensity of the feature in points for each strategy of behaviour. The most preferred behaviour strategies, both for the younger and for the older adolescents with intellectual disabilities, are rivalry, adaptation, and avoidance (see Fig. 2).

The behaviour of teens with intellectual disabilities in the choice of rivalry is characterised by the desire to insist on his/her own, willingness 
to engage in an open struggle for his/her own interests, neglecting the interests of another person, accusing others, demanding solving the problem for him/her. This indicates an unformed personality and selfawareness of teens with intellectual disabilities. It also emphasizes the discrepancy between personal expectations and the requirements of the social environment for this category of children. The fact that the level of rivalry from younger teens to the older ones practically does not change $(t=-1.59, p=0.11)$ testifies to the later formation of the personality of the adolescents with intellectual disabilities.

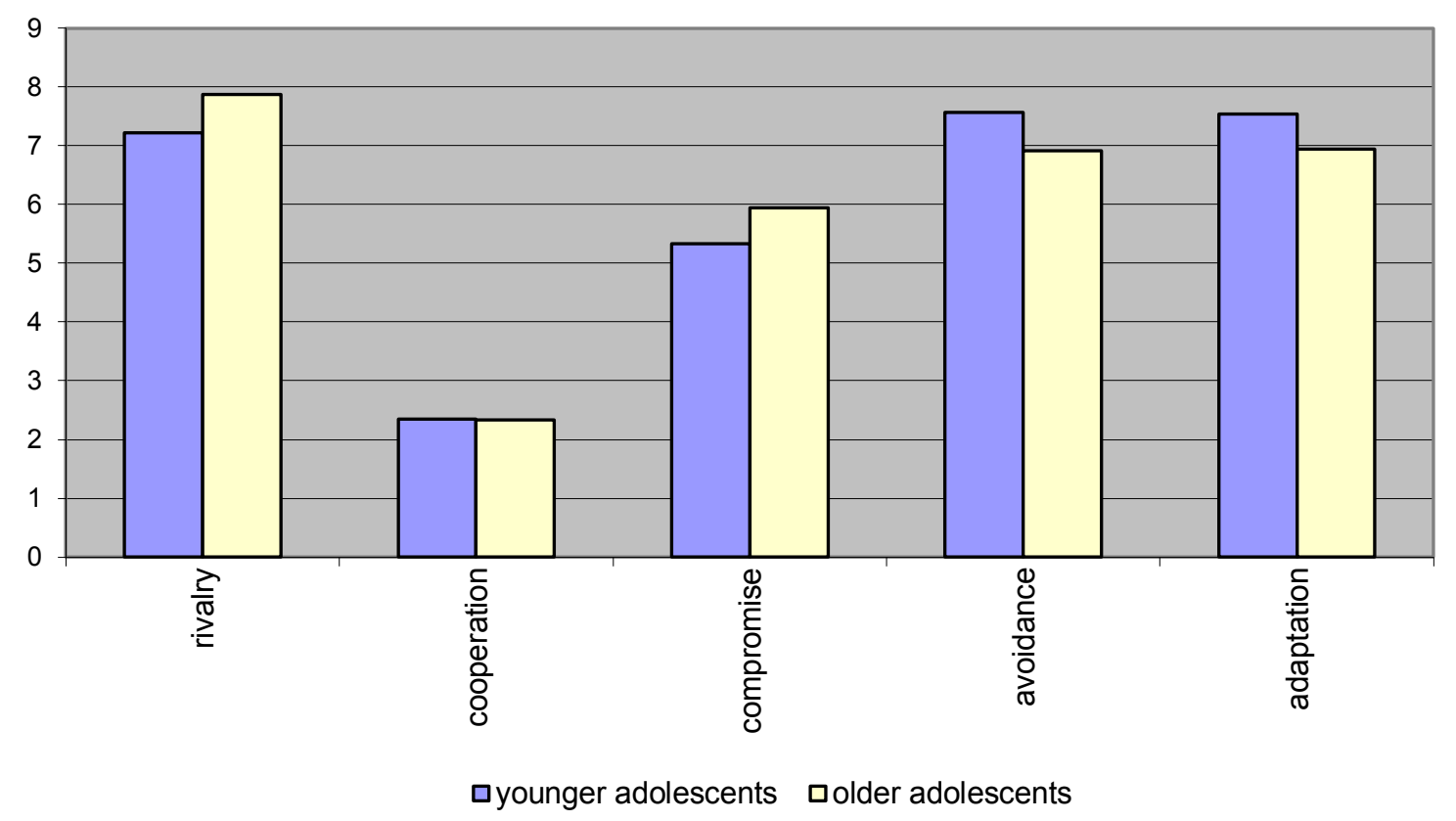

\section{Fig. 2. Types of Behaviour of Adolescents with Intellectual Disabilities in Conflict Situations (Quantitative Indicator of the Feature Intensity in Points)}

In children with normal development, the level of rivalry over the years reduces $(\mathrm{t}=2.68, \mathrm{p}=0.021)$, since their social status and personal expectations adequately correlate, whereas self-awareness increase leads to higher tolerance, i.e. acceptance of other people's opinions, and selfcontrol. Thus, the difference in the dynamics of rivalry from younger to senior adolescents in general education and special school reveals qualitative differences in these groups. Avoidance of the conflict and partial refusal to seek alternative solutions indicates passive social position of adolescents with intellectual disabilities. The main reason here lies in the underdevelopment of the cognitive and personal spheres of these students. 
When the emotional and volitional manifestations of adolescents with intellectual disabilities experience enormous social and emotional burden, which is a conflict, they prefer to avoid this conflict situation. Adolescents from general education schools are also characterised by avoidance of the conflict, but the number of avoidants decreases significantly $(\mathrm{t}=3.12$, $p=0.003$ ) for senior classes, which indicates an increase in the degree of personality activity of the surveyed students.

The adaptation strategy is expressed in the desire to preserve the relationship, the willingness to give up and obey contrary to their interests. The quantitative indicator of adaptation in the conflict is not different among adolescents of general education and special schools. However, observations show qualitative differences in this feature in different groups. In adolescents with intellectual disabilities, this is due to the underdevelopment of the volitional sphere, the inability to defend their point of view, with pronounced conformity. One more reason for the avoidance and adaptation of such adolescents in the conflict is the immatureness of moral norms + forced submission to the requirements of others. The only factor that restrains their aggressiveness is the fear of punishment (a high sense of guilt). Thus, they are characterised by a constant conflict between conscientiousness and a sense of guilt, which leads to the increase in negative emotional states. Adolescents with normal development, more prone to reflection and responsibility, tend to obey to stereotypes and rules. They often occupy a passive submission position basing on moral norms, and the level of electoral adaptation increases before high school age $(\mathrm{t}=-2.44, \mathrm{p}=0.018)$.

There is a tendency towards the reduction of socially passive forms of response in the situation of conflict in adolescents (avoidance, adaptation) till senior classes of special school, but it is not significant $(\mathrm{t}=1.93, \mathrm{p}=0.056 ; \mathrm{t}=1.68, \mathrm{p}=0.095)$.

In the interpersonal sense, the ability of the group members to compromise in a conflict situation, to strive to bridge differences, to cave on in exchange for a climb-down, to seek a middling solution has a great importance, especially when it comes to dyadic communication. The choice of this strategy is most often used when the object of conflict is not of great importance to the parties, there is no depth of understanding of his/her purpose, then teens are ready to cave on if the "opponent" gives in to them. This strategy is equally inherent in adolescents from both groups. 
Extremely rarely, for the resolution of conflict situations, adolescents with intellectual disabilities use collaboration. The main reason lies in the weakness and inertia of the neural processes in these adolescents compared with the norm, which prevents them from making quick switching, taking into account both the situation and perceptions, as well as the understanding of their own and others' behaviour in it. Consequently, taking into account the aforementioned and the relevant quantitative data, we can state that adolescents with intellectual disabilities have poorly developed actualisation of social experience, the awareness of the situation, the ability to regulate their behaviour and the activation of reference formations, which are necessary for compromise and cooperation. Moreover, without any corrective work, the level of cooperation and compromise from younger to senior adolescents does not change $(\mathrm{t}=0.06, \mathrm{p}=0.95 ; \mathrm{t}=-1.52, \mathrm{p}=0.13)$. Teens from general education schools are more likely to cooperate $(\mathrm{p}<0.01)$, i.e. in a conflict situation they are ready to realise the need to understand the claims of another person in dyadic communication and adequately assess the positions of the other side.

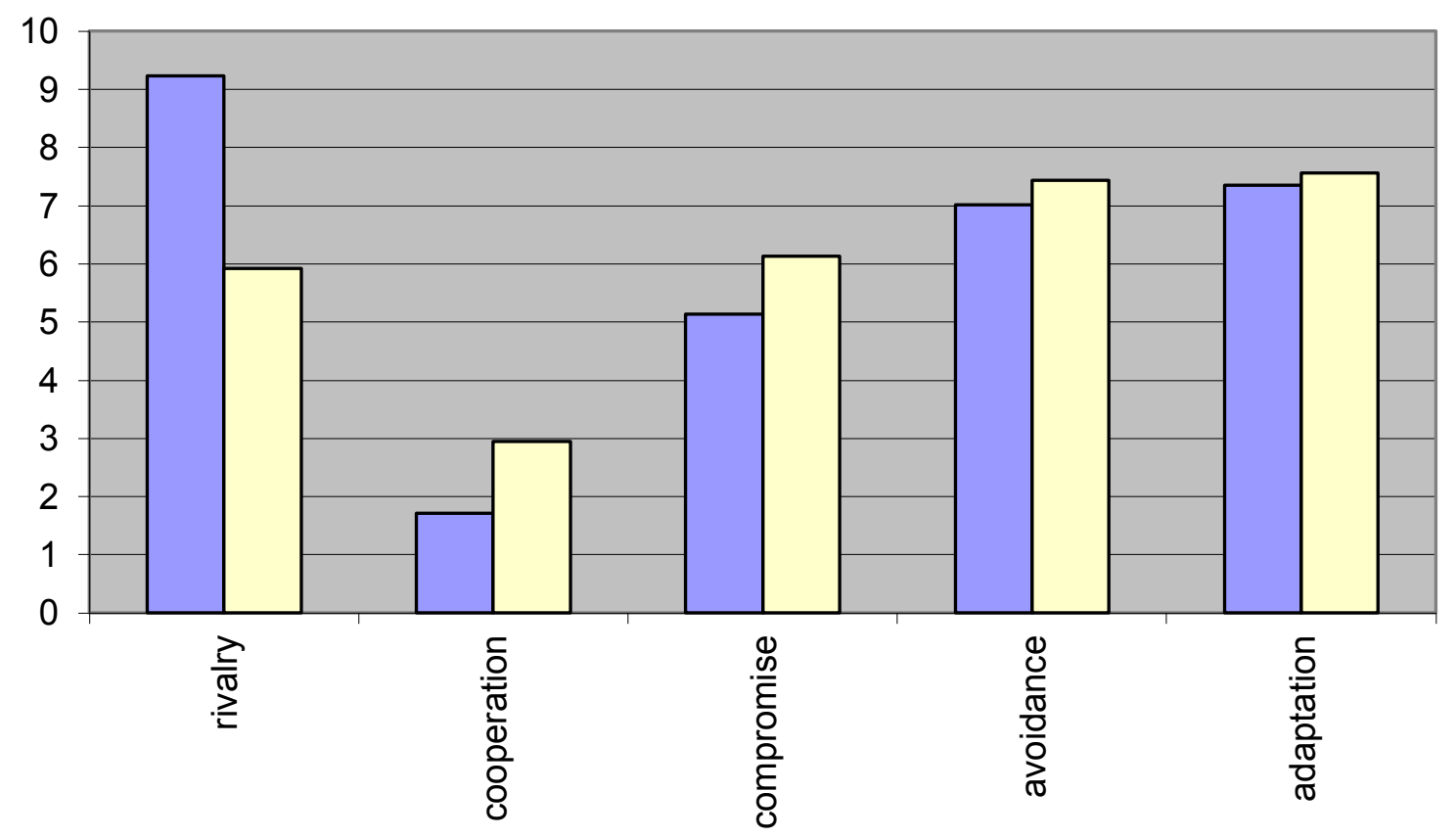

口boys $\quad$ girls

Fig. 3. Behaviour Types of Adolescents with Intellectual Disabilities in Conflict Situations (Quantitative Indicator of the Feature Intensity in Points) 
It should be noted that there are gender differences in the manifestation of different behaviour strategies of adolescents with intellectual disabilities in a conflict situation (see Fig. 3).

Thus, boys with intellectual disabilities demonstrate higher competition in a difficult situation $(\mathrm{p}<0.01)$, than girls, indicating potential readiness for conflict. An unsolvable situation for them becomes a trigger for aggressive behaviour. Whereas girls are inclined to avoid open confrontation, adapt to the situation, compromise. In addition to that, girls are more likely to cooperate in conflict $(\mathrm{p}<0.01)$ than boys, they even show responsibility for the occurrence and correction of this situation. There is a similar situation in general education school, but it is interesting that the ability to compromise there is more pronounced in boys than in girls $(\mathrm{p}<0.05)$. Furthermore, in the same group, there is a slight decrease in compromise indicators for senior classes in favour of cooperation.

Answers received for the adapted version of $\mathrm{K}$. Thomas model were thoroughly checked with observation protocols regarding the behaviour of adolescents in conflict situations. In the observation, the researchers used a scheme basing on the principles of critical or frustrating situation as described by S. Rosenzweig ${ }^{10}$.

In order to find out the differences in the types of manifestations of the same behaviour strategy in adolescents and the direction of these strategies, the team used Rosenzweig's projective technique ${ }^{11}$.

S. Rosenzweig highlights three ways of behaviour in a critical situation - a response with concentration on ego defence, obstruction and satisfaction of needs. Considering the direction the scientist distinguish extra, intra-and intuitive responses. While examining the results of the research based on Rosenzweig Picture Association Test, it was revealed that there are no reliable differences in the methods of response in a conflict or critical situation in groups of adolescents with normal development and with intellectual disabilities (see Fig. 4). Extra-punitive responses (E) prevail in both older and younger adolescents. This result can be interpreted as follows: many of them are more likely to blame others in an unsuccessful situation then than

10 Лукин С.Е. Суворов А.В. Тест рисуночной ассоциации Розенцвейга (руководство по использованию). СПб., 1993. С. 43.

${ }^{11}$ Там же. 62 c. 
themselves or objective circumstances, therefore they demand meeting their needs from others. It turned out that in adolescents, non-punitive responses (M) were developed to a lesser extent, when the conflict situation itself was seen as insignificant and inevitable. As for the responsibility of the teenager himself/herself for the incident (I), this response is quite pronounced in all adolescents. There is a uniform distribution of responses with fixation on the satisfaction of continued need (NP), on ego defence (ED) and on obstacle dominance (OD) in a group of teenagers with normal development, and this distribution is preserved from younger grades to senior ones. In the group of young adolescents with intellectual disabilities, the response with obstacle dominance (OD) prevails over the response with continued need (NP), whereas the situation for the older adolescents is exactly the opposite. The response with fixation on ego defence (ED) does not significantly change with age.

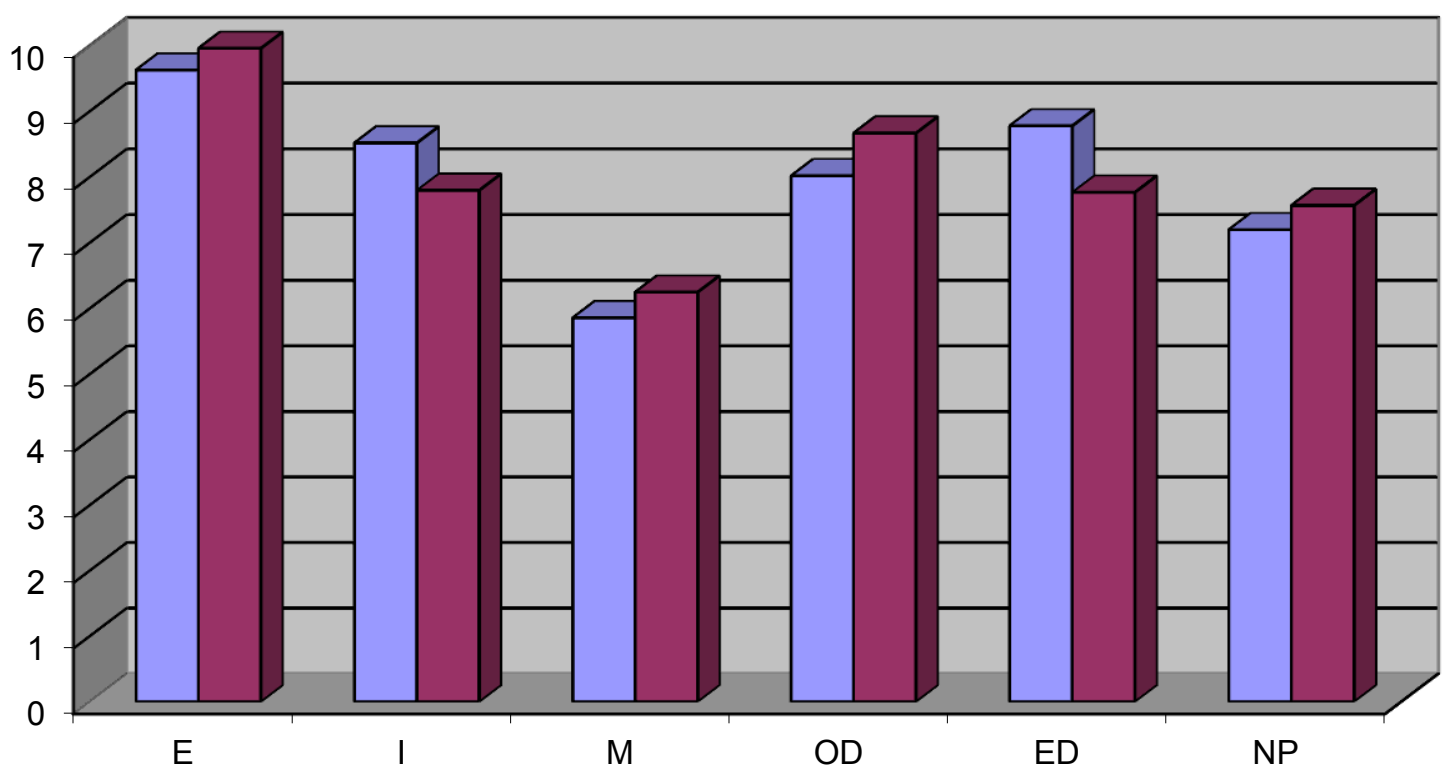

口adolescents with intellectual disabilities

口adolescents with normal development

Fig. 4. Types and Directions of Behavioural Responses to Conflict in Adolescents with Intellectual Disabilities and Normal Development (Quantitative Indicator of the Feature Intensity in Points) 
It should be outlined that there are gender differences in the manifestation of these responses both in adolescents with intellectual disabilities and in adolescents with normal development. For instance, intra-punitive (I) responses are more typical for girls $(\mathrm{p}<0.01)$ than for boys, with the responsibility for the occurrence and correction of this situation. On the contrary, boys more often demonstrate extra-punitive (E) responses $(\mathrm{p}<0.01$ for those with intellectual disabilities, $p<0.05$ for those with normal development).

In other words, boys more often than girls choose tactics of behaviour blaming the outside environment, while girls more often shoulder the blame and take responsibility. Thus, girls, in contrast to boys, are more oriented towards the rules and regulations in their behaviour. Boys most frequently demonstrate ego defence responses ( $p<0.01$ for those with intellectual disabilities, $p<0.05$ for those with normal development), blaming someone, shouldering the blame or avoiding the blame - all actions are aimed at protecting their own ego. For girls who are more inclined to blame themselves, a conflict insurmountable situation can become the cause of leaving or adapting with subsequent neuroticism. For boys who are more prone to look for causes of failure outside, the insurmountable conflict situation is the impetus for rivalry with manifestations of aggression and violations of social norms.

This explains easier and more comfortable socialisation of girls both in general education and in special school, as girls' activities are largely aimed at subordinating to the norms and stereotypes that ensure the resolution of many conflict situations.

We would like to emphasize how the responses of adolescents with intellectual disabilities to failure and difficult insurmountable situations and ways of resolving these conflict situations are interrelated. The rivalry among younger and older adolescents correlates with extrapunitive $(\mathrm{E})$ responses $(\mathrm{r}=0.83 ; \mathrm{r}=0.81$ correspondingly) and ego defence (ED) responses $(r=0.63 ; r=0.31$ correspondingly). When trying to cope with the conflict, the teenager blames others, requires them to solve the problem, protects his own Self, goes on an open clash, typically with equal ones, defends his/her positions, seeks to prove that the other person is wrong, trying to overturn him/her, to use physical violence, to call for the help of others. In addition to that, extra-punitive responses 
and ego defence responses (ED) are interrelated in younger $(\mathrm{r}=0.61)$ and older $(\mathrm{r}=0.43)$ adolescents.

In younger and older adolescents with intellectual disabilities, adaptation correlates with intra-punitive (I) responses $(\mathrm{r}=0.39 ; \mathrm{r}=0.43$, respectively) and obstacle dominance (OD) responses ( $\mathrm{r}=0.43 ; \mathrm{r}=0.37$ respectively). The situation seems to be insurmountable to adolescents, they suppress their negative emotions more often because of fear, bear with what is happening, in order not to disturb peace, transfer aggressive emotions into the inner sphere, worry, often cry, silent, harbouring thoughts of revenge. Intra-punitive responses have inverse correlations with the extra-punitive ones ( $\mathrm{r}=-0.79 ; \mathrm{r}=-0.81$, respectively). Intrapunitive responses are interconnected with responses of continued need in both younger $(\mathrm{r}=0.62)$ and older $(\mathrm{r}=0.48)$ adolescents. They also have inverse correlations with ego defence responses $(r=-0.54)$ in younger teens.

In case of choosing avoidance strategy, there is not enough correlation with the directions and types of responses in older adolescents; there is a tendency to interrelate only in girls. Here, the avoidance correlates with the intra-punitive $(\mathrm{I})$ response $(\mathrm{r}=0.44)$ and the response with obstacle dominance $(r=0.37)$. Avoidance typically includes demonstration removal, abused care, tears, concealed anger, ignorance of the offender, complete abandonment of relationships. Younger adolescents show a tendency of interrelation between avoidance and non-punitive $(\mathrm{M})$ responses $(\mathrm{r}=0.42)$. This suggests that they tend to avoid conflicts more often in cases of insignificance, superficiality of goals and interests in the situation.

While examining the results of the correlation of compromise and cooperation with the types and directions of response, younger adolescents did not have explicit preferences in the choice. In older teenagers with intellectual disability, the compromise correlates with the non-punitive $(\mathrm{M})$ response $(\mathrm{r}=0.35)$, collaboration - with intra-punitive (M) response $(\mathrm{r}=0.5)$ and response with fixation on continued need $(\mathrm{r}=0.5)$. It should be noted that the non-punitive $(\mathrm{M})$ response correlates with the response aiming to satisfy continued need (NP) in older adolescents $(\mathrm{r}=0.37)$ and in older and younger girls $(\mathrm{r}=0.37)$.

The obtained results allow us to talk about the choice of behaviour of a teenager with intellectual disabilities as a result of his/her socialisation. Hence, on demand: "Give me the push scooter!" we often saw such 
answers as: "I will not give it!", "You wish, it's mine" or "You can wait", less often, more preferable for girls: "Take it!" or "Let's roll together". The phrase: "Finally I caught you!" provoked such answers as: "Leave me alone!", "It's their fault!", "I've simply passed by, catch the other ones" or "Sorry, please, I will be good", "Let me go, I'll tell my mom".

A teenager solves a difficult situation basing on the norms facilitated by the family, school, and closest entourage. An adolescent show his/her worth aggressively, submissively or independently. On the basis of these materials, we can talk about the mechanisms of socialisation in overcoming conflict situations, namely active-offensive (aggressive or constructive) and passive-defensive (obedient or responsible). If, due to intellectual underdevelopment, moral norms are not mastered sufficiently, control over their actions and actions is not developed, the situation is not perceived adequately, then it is possible to speak more about affective responses towards what is happening, and these responses were included as the elements of extra-, intra- and nonpunitive responses. We will deal with the aggressive or subordinate mechanism of socialisation. Let's say, some teens with intellectual disabilities showed such prevailing responses: "Let me sit quietly. Leave me alone", "Please, let me swing, too, you got some nerve!", "Look who's talking!", "You wish! I'll be drumming", "You would fall like that!" Other answers included: "I'm sorry, I did not want to do it", "I'm sorry, I will be good", "Okay", "Oh well..." It is curious that in some cases these responses were intermittent in the same adolescents.

After analysing the data obtained, one can conclude that a high level of aggressiveness or submissiveness is due to low socialisation in the peer group. The average rate of adaptation to social environment according to Rosenzweig's technique in the group of younger teens is GCR $=33.3 \%$, among older teens it is $=42 \%$. These children place high demands on others, this often serves as a sign of inadequate and unstable self-esteem and impedes interpersonal contacts with other adolescents.

We should underline that in the group of adolescents from general education schools GCR $=51 \%$ in junior classes and $69 \%-$ in senior ones.

At the same time, normal teenagers also quite often conflict with each other, subsequently explaining it by the fact that refusal from rivalry can be perceived as a concession and a path to defeat. Moreover, in critical and conflict situations, adolescents from general education 
schools often choose continued need (NP) response (search for a way out, a constructive solution, desire to meet the needs, not to leave the situation unresolved) along with ego defence (E).

Therefore, in teenagers with intellectual disabilities, the choice of behaviour in conflict depends on the level of their socialisation and is conditioned by their conflicting relationships between internal and external behaviour regulators. Namely, on the one hand, they are characterised by the immaturity of moral norms, but, on the other hand, they are compelled to obey the requirements of others. The only factor that restrains their aggressiveness is the fear of punishment (a high sense of guilt). Thus, they are characterised by a constant conflict between conscientiousness and a sense of guilt, which leads either to rivalry with the strengthening of negative responses, or to avoidance and adaptation with suppression of their emotions due to fear of an opponent or punishment.

The study also intended to detect the influence of the peculiarities of neurodynamics and the defect structure on the behaviour of adolescents with intellectual disabilities in the conflict. In order to do this, all study subjects were divided into groups according to the clinical behaviours described by M. Pevzner ${ }^{12}$. When comparing, we noted behavioural patterns characteristic for each group and revealed the fact that the dominant strategy is rivalry. Nevertheless, the research has shown that this strategy manifests itself differently in adolescents from different groups. During the correlation and comparative analysis between the groups, the scholars found that in some cases there was verbal and nonverbal aggression, open struggle and confrontation, the desire to achieve the own goals in any way, to meet the own needs. In other cases, rivalry turned out to be a stumbling block in the conflict. We marked this strategy with the same name. It is characterised by extrapunitive resistance and resolving responses: fixation on the purpose and problem, inability to distract, break in the activity, inability to make any decision, affective-dynamic reactions (irritation, anger of high intensity, self-aggression and aggression directed towards outsiders or objects, crying, feeling of helplessness, rigidity of emotions, desire for immediate changes in everything). When a teenager is stuck, s/he cannot

12 Певзнер М.С. Дети с интеллектуальными нарушениями: Изучение детей в процессе их обучения и воспитания. М. : Педагогика, 1959. 489 с. 
get out of a problem situation, s/he wants to solve it, end it, but at the expense of another person, regardless of who actually created the critical situation. With such typical behaviours, a teenager can cry for a long time, scream, "go nuts", scatter things, and demonstrate no response to the actions of others, who are trying to shift his/her attention. Most often, a stumbling block is found in a group of adolescents with psychopathic manifestations (64.61\% of all rivalry choices), with a lack of frontal lobes (50\% of all rivalry choices), as well as adolescents with neurodynamic violations (with excitation superiority of $30.32 \%$; inhibition $-52.97 \%$, with the weakness of both processes $-25.29 \%$ of all rivalry choices).

The compromise also manifests itself in different ways in adolescents with intellectual disabilities. In some groups, this was a conscious strategy of behaviour, the ability to regulate their actions. In others, it was a patterned stereotype of behaviour, not motivated by circumstances. The adolescents of the main group and adolescents with a violation of the analysers appeared to be more capable of a conscious compromise in the conflict situation (6.91 and 6.64 out of 30 correspondingly).

The choice of cooperation is highest in the first (main) group of adolescents without extreme violations of neurodynamics and analysers (3.27). A fairly high level of cooperation and compromise in adolescents with an uncomplicated form of oligophrenia can actively influence the formation of a productive behaviour strategy among students in this group. The fact of high (in comparison with other groups) cooperation in adolescents with a predominance of inhibition processes over excitation (third group) needs a special explanation (3.66 out of 30). The lack of awareness of the situation by these teenagers makes their reactions to the conflict monotypic, subordinate, with the choice of an intra-punitive obstacle-dominant orientation, which is characterised by subordination, self-accusation, confession that they are a cause of a critical situation, avoidance or obedience. However, obedience to the norms, requirements and rules of others in conditions of educational process at school helps these adolescents to memorize stereotypes, patterns of behaviour that solve a conflict situation. This explains some increase in cooperation in this group of adolescents and, as the study shows, this trend becomes visible in the usual recurring conflict situations at school. 
We strongly believe that all revealed peculiarities of conflict behaviour in teens with intellectual disabilities compose sufficient material necessary for creating a complete psychological picture and organising productive corrective work on prevention and constructive resolution of conflicts in the behaviour of adolescents at special school.

\section{CONCLUSIONS}

1. The developed complex research procedure allows to study the features of conflict behaviour effectively, its causes and the ways of resolving conflicts that are typical for adolescents with intellectual disabilities, which is the basis for the specification of the directions of psychological and pedagogical work with this category of students.

2. The causes of conflictual behaviour in adolescents with intellectual disabilities include biological ones, related to the structure of the defect and the peculiarities of neurodynamics; psychological ones, associated with the peculiarities of personal development and subjective perception of the situation; social ones, associated with the conditions of a teenager development in the immediate social environment (family, school).

3. Prevailing strategies of conflict behaviour in adolescents with intellectual disabilities are destructive types (rivalry, adaptation, avoidance). Teenagers with a predominance of excitation processes, with psychopathic and frontal syndromes are the most susceptible to rivalry. Adaptation and avoidance more often appears in torpid adolescents and adolescents with various violations of analysers. In students with intellectual disabilities with an uncomplicated form of oligophrenia, the percentage of selecting cooperation and compromise is rather high, compared to other groups, and therefore the development of these strategies is the "zone of immediate development" of such adolescents.

4. There are gender differences in the choice of the behaviour strategy in conflict by adolescents with intellectual disabilities. Boys are more likely to use rivalry in conflict than girls; for girls, passive forms of behaviour (adaptation, avoidance) are more typical, as well as productive strategy, i.e. cooperation.

5. For teenagers with intellectual disabilities, there is a special distinctive type of behaviour in conflict, which is a so-called stumbling block. When this behaviour type floats to the surface, the teenager is not able to cope with the situation on his/her own. More often, a stumbling 
block is found in a group of adolescents with psychopathic manifestations, as well as in adolescents with neurodynamic violations.

6. The obtained psychological information allows determining directions and conditions of differentiated, individualised corrective work, in particular, group psychocorrection with the aim of preventing conflicts and conflicting behaviour among adolescents with intellectual disabilities, and creates psychological preconditions for socialisation.

The conducted study does not exhaust all aspects of the issue. Conflicts between younger students with intellectual disabilities, as well as youth, and the peculiarities of their behaviour, which determines conflict situations require further study. Furthermore, research should focus on the in-depth study of family conflicts among students of special schools.

\section{SUMMARY}

The research is devoted to the study of biological, psychological and social causes of conflicts in adolescents with intellectual disabilities, as well as the peculiarities of their behaviour in conflict situations. To this end, the authors revealed subjective preconditions for the emergence of conflicts. The results of the study showed the dependence of conflict behaviour on the level of well-being of the family, the attitude of family members towards the adolescent, and the style of family education, which affects the formation of particular stereotypes of behaviour: dependent, detached or aggressive. The paper revealed the objects of positive and negative appraisals of adolescents with intellectual disabilities of their family status.

During the study, the scholars noted positive and negative factors of school life, influencing the formation and predominance of behaviour strategies of adolescents with intellectual disabilities in conflict situations.

The article discovered the dependence of the choice of different strategies of conflict behaviour on the level of mental development, the structure of the defect, as well as the age and gender characteristics of adolescents. The authors named prevailing strategies in the behaviour of teenagers with intellectual disabilities. The research included a more indepth analysis of the types of behaviour distinctive for adolescents with intellectual insufficiency in difficult-to-solve situations, and after taking 
into account the structure of their defect and neurodynamics they identified this type of behaviour in conflict as a stumbling block.

\section{REFERENCES}

1. Бистрова Ю.О. Забезпечення наступності в процесі професійно-трудової соціалізації осіб 3 вадами інтелектуального розвитку : монографія. Луганськ : Вид-во ДЗ «ЛНУ імені Тараса Шевченка». 2012. С. 156-217.

2. Бистрова Ю.О., Синьов В.М. Діагностика індивідуальнопсихологічних рис особистості як початковий етап процесу професійно-трудової соціалізації учнів 3 особливими освітніми потребами. Nowoczesna edukacja: flozofa, innowacja, doświadczenie. Nr1. Łódź : Wydawnictwo Naukowe Wyższej Szkoły Informatyki i Umiejętności, 2015. P. 120-129.

3. Божович Л.И. Избранные психологические труды. Проблемы формирования личности. / под ред. Д.И.Фельдштейна. М. : Международная педагогическая академия, 1995. 349 с.

4. Ложкин Г.В., Повякель Н.И. Практическая психология конфликта. К. : МАУП, 2002. С. 66-74.

5. Лукин С.Е. Суворов А.В. Тест рисуночной ассоциации Розенцвейга (руководство по использованию). СПб. 1993. 62 с.

6. Певзнер М.С. Дети с интеллектуальными нарушениями: Изучение детей в процессе их обучения и воспитания. М. : Педагогика, 1959. 489 с.

7. Спеціальна психолого-педагогічна діагностика / за ред. Ю.О. Бистрова, В.С. Коваленко. Харків: Майданс, 2018. 170 с.

\section{Information about the author:} Bystrova Yu. O.

Doctor of Psychological Sciences, Professor of the Department of Psychocorrectional Pedagogics National Pedagogical Dragomanov University 9, Pyrohova str., Kyiv, 01601, Ukraine 